\title{
Article \\ Foliar Thidiazuron Promotes the Growth of Axillary Buds in Strawberry
}

\author{
Yali $\mathrm{Li}^{1}{ }^{1}$, Jiangtao $\mathrm{Hu}^{1}{ }^{1}$, Jie Xiao ${ }^{1}, \mathrm{Ge} \mathrm{Guo}^{1}$ and Byoung Ryong Jeong ${ }^{1,2,3, *(D)}$ \\ 1 Department of Horticulture, Division of Applied Life Science (BK21 Program), \\ Graduate School of Gyeongsang National University, Jinju 52828, Korea; leeyali@gnu.ac.kr (Y.L.); \\ hujiangtao@gnu.ac.kr (J.H.); xiaojsicau@163.com (J.X.); rainbowmaomao317@gmail.com (G.G.) \\ 2 Institute of Agriculture and Life Science, Gyeongsang National University, Jinju 52828, Korea \\ 3 Research Institute of Life Science, Gyeongsang National University, Jinju 52828, Korea \\ * Correspondence: brjeong@gnu.ac.kr; Tel.: +82-55-772-1913
}

Citation: Li, Y.; Hu, J.; Xiao, J.; Guo, G.; Jeong, B.R. Foliar Thidiazuron Promotes the Growth of Axillary Buds in Strawberry. Agronomy 2021 11, 594. https://doi.org/10.3390/ agronomy11030594

Academic Editor: Alessandro Miceli

Received: 19 January 2021

Accepted: 19 March 2021

Published: 21 March 2021

Publisher's Note: MDPI stays neutral with regard to jurisdictional claims in published maps and institutional affiliations.

Copyright: (C) 2021 by the authors Licensee MDPI, Basel, Switzerland. This article is an open access article distributed under the terms and conditions of the Creative Commons Attribution (CC BY) license (https:/ / creativecommons.org/licenses/by/ $4.0 /)$.

\begin{abstract}
Strawberry (Fragaria $\times$ ananassa Duch.) can be easily propagated with daughter plants or through crown division, which are developed from the axillary bud at the axils of leaves. This study was conducted to investigate the effects of different cytokinins, auxins, and their combinations on the axillary bud growth in strawberry. Four cytokinins (6-benzyladenine, kinetin, zeatin, and thidiazuron (TDZ) ) and three auxins (indole-3-acetic acid, indole-3-butyric acid, and naphthaleneacetic acid) at a concentration of $50 \mathrm{mg} \cdot \mathrm{L}^{-1}$ were sprayed on the leaves three times in 10-day intervals. The expression levels of cytokinin, auxin, and meristem-related genes in the crowns were also investigated. The results showed that TDZ was the most effective hormone for the axillary bud growth, and also promoted plant growth. However, chlorophyll, soluble sugar, and starch contents in the leaves were lower after TDZ. TDZ activated the cytokinin signal transduction pathway, while repressing the auxin synthesis genes. Several meristem-related transcription factors were upregulated, which might be essential for the growth of the axillary buds. These results suggested that TDZ can improve the cultivation of strawberry, while further research is needed to explain the effect on phytochemistry.
\end{abstract}

Keywords: hormone; meristem; cytokinin; auxin; transcription factors

\section{Introduction}

Strawberry (Fragaria $\times$ ananassa Duch.) is an important crop throughout the world. It can be easily propagated with daughter plants on runners or by crown division. The plant has a very short main stem, which is called the primary crown [1]. Both the runners and branch crowns developed from the axillary meristem (AXM) at the axils of leaves on the primary crown. Generally, the fate of the AXM depends on its location on the primary crown, since the AXM at the axil of the uppermost leaf has the priority to develop into either a runner or a branch crown [2]. This is controlled by the cultivar and the environment [3]. It is well known that long days and high temperatures induce runner formation [4]. Branch crowns are generally formed when the growth of the primary crown slows and runner formation ends in late summer or mid-fall [1]. The photoperiod and temperature begin to drop at this time, and the plants transition into the reproductive phase. Meanwhile, extension of the crown continues along the axis of the uppermost lateral meristem, giving a sympodial structure to the crown.

Plant growth regulators (PGRs) are essential for AXM initiation and axillary bud growth. Cytokinin and auxin coordinate axillary bud growth. Cytokinin is mainly synthesized and exported from the roots, whereas auxin is mainly synthesized in the terminal bud and transported basipetally [5]. A high cytokinin-to-auxin ratio in the axillary buds triggers bud growth [6]. Moreover, a similar mechanism was identified in strawberry runners recently. Researchers found that high auxin activity is present in the dormant bud, while high cytokinin activity is found in the non-dormant bud. Furthermore, decapitation 
and pharmacological experiments of the dormant buds showed that the reduction of auxin and exogenous cytokinin application trigger the regeneration of vegetative shoots [7].

The plant hormone signal transduction is the most significant pathway during axillary bud growth in strawberry. Researchers found 439 core differentially expressed genes (DEGs) between dormant and non-dormant buds. Based on the functional annotations, cytokinin and auxin metabolism/signaling related DEGs were identified as the two dominant pathways $[7,8]$. In addition, the importance of sucrose to modulate bud growth in plants has been reported $[9,10]$. The significantly different expression of starch and sucrose metabolism-related genes in the dormant and non-dormant buds indicated that starch and sucrose metabolism are involved in the regulation of axillary bud growth in strawberry $[7,11]$.

Most commercial strawberry cultivars in Korea belong to a seasonal flowering type, which means fruiting is limited by the season. Since strawberries are popular all over the world, researchers are devoted to produce year-round strawberries. The first step for this is to achieve propagation in different seasons. Runner and branch crown are two main propagation methods, and both are developed from axillary buds. The growth of the axillary buds is controlled by cytokinin and auxin. Different types of natural and synthetic cytokinins and auxins are currently available. Kinetin (KT), zeatin (ZT), isopentenyladenine, and dihydrozeatin are the dominant natural cytokinins found in higher plants [12,13], while several synthetic cytokinins such as 6-benzyladenine (6-BA) and thidiazuron (TDZ) are also available [14,15]. Natural auxins such as indole-3-acetic acid (IAA) and indole-3-butyric acid (IBA), together with the synthetic auxin 1-naphthaleneacetic acid (NAA) are the most popular auxins [16]. This study was conducted to investigate the growth of axillary buds as affected by cytokinins, auxins, and their combinations, in order to assist the propagation of strawberry in winter.

\section{Materials and Methods}

\subsection{Plant Materials}

Plants of strawberry 'Seolhyang' were cut from mother plants and stuck into 21-cell trays filled with the BVB Medium (Bas Van Buuren Substrate, EN-12580, De Lier, Westland, The Netherlands) on 1 November 2019. They were placed on a propagation bench with fogging. After two weeks of rooting, the plants were moved to benches in a glasshouse at Gyeongsang National University, Jinju, Korea and grown for two weeks. Thereafter, the plants were transplanted to $10-\mathrm{cm}$ pots for further experiment. Five levels of cytokinin (no cytokinin, BA, TDZ, kinetin, and zeatin) and four levels of auxin (no auxin, IAA, IBA, and NAA) were used in this experiment. All the cytokinins and auxins including their mixtures were used at a concentration of $50 \mathrm{mg} \cdot \mathrm{L}^{-1}$. Each combination of cytokinin and auxin was mixed as one solution. These PGR solutions were sprayed on the leaves until the solution began to drip. The PGR solutions were applied three times at an interval of 10 days starting on 7 December 2019. The mean daily temperature, relative humidity, photoperiod, and solar radiation during this period were $14.5^{\circ} \mathrm{C}, 90 \%, 10 \mathrm{~h}$, and $200 \mu \mathrm{mol} \cdot \mathrm{m}^{-2} \cdot \mathrm{s}^{-1} \mathrm{PPFD}$, respectively. The experiment was laid out in a completely randomized design with three replicates of seven plants. Samples of leaves and crowns were collected from three uniform plants in each replicate. The experimental data were collected on 6 February 2020.

\subsection{Growth}

The numbers of runners, branch crowns, and flowers per plant, plant height, leaf length, and leaf width were measured after two months.

\subsection{Chlorophyll}

Chlorophyll content was estimated according to Wang et al. [17] with some modifications. The fresh leaves were ground into a powder in liquid nitrogen, and $0.02 \mathrm{~g}$ of the powder mixed with a $2 \mathrm{~mL}$ extraction buffer ( $45 \%$ v/v ethanol, $45 \%$ v/v acetone, and $10 \%$ distilled water). The mixtures were covered with tin foil and put into a $4{ }^{\circ} \mathrm{C}$ refrigerator 
overnight. After centrifugation at $6000 \mathrm{rpm}$ for $10 \mathrm{~min}$, the supernatants were transferred to a colorimeter tube for determination of the absorbance at 645 and $663 \mathrm{~nm}$. The chlorophyll contents were determined using the following formulae:

$$
\text { Total chlorophyll content }=\frac{(20.29 \times \text { OD } 645+8.05 \times \text { OD } 663) \times \mathrm{V} *}{\text { Sample fresh weight }}
$$

${ }^{*} \mathrm{~V}$, volume of the extraction solution. The chlorophyll content was presented as mg of chlorophyll per $\mathrm{g}$ of fresh leaf weight)

\subsection{Soluble Sugar and Starch}

The soluble sugar and starch contents in leaves were determined according to previously described methods [11].

\subsection{RNA Preparation and Quantitative RT-PCR}

The growth of the axillary buds was most significantly increased with TDZ. To further identify whether or not TDZ regulates bud growth, the expression levels of genes related to auxin and cytokinin, and several transcription factors were assessed in crown samples supplied with or without TDZ. The crowns of the plants in the control, and those treated with TDZ alone were ground into a fine powder in liquid nitrogen for RNA extraction. The total RNA was extracted using the Easy-Spin Total RNA Extraction Kit (Intron Biotechnology, Seoul, Korea). The quantity and quality of the RNAs were determined with the NanoDrop 2000c Spectrophotometer (Thermo Fisher Scientific, Waltham, MA, USA). First-strand cDNA was synthesized using the Prime-Script ${ }^{\mathrm{TM}}$ RT reagent Kit with gDNA Eraser (Takara Bio Inc., Otsu Shiga, Japan) according to the specifications, and the cDNA were diluted tenfold for the qRT-PCR analysis.

The expression levels of four cytokinin synthesis and metabolism-related genes $(\mathrm{Cy}$ tokinin Oxidase (CKX), Isopentenyltransferase (IPT), Response Regulator (RR), and Histidine Phosphotransmitter $(H P)$ ), three auxin-related genes (Auxin Response Factor (ARF), Small auxin up RNA (SAUR), and IAA4), and eight meristem-related transcription factors (Wuschel (WUS), WUS homeobox-containing (WOX), Shoot Meristemless (STM), LEAFY(LFY), two CupShaped Cotyledon (CUC) genes, a DELLA gene (RGA1), and Suppressor of Overexpression of Constans1 (SOC1)) were detected through the qRT-PCR analysis. The primers of FaWUS, FaSOC1, and FaRGA1 were designed according to the identified sequences (Table 1). Other primers were the same as those found in Qiu et al. [7] used in strawberry. Actin 2 was selected as the housekeeping gene to normalize the results of the qPCR. The iQ ${ }^{\mathrm{TM}}$ SYBR Green Supermix (Bio-Rad, Hercules, CA, USA) was used to detect the PCR products on the CFX96 real-time PCR system (Bio-Rad, Hercules, CA, USA). A total of $20 \mu \mathrm{L}$ reaction volume was constructed with $1 \mu \mathrm{L}$ each of forward and reverse primers, $1 \mu \mathrm{L} c \mathrm{cNA}, 10 \mu \mathrm{L}$ SYBR green, and $7 \mu \mathrm{L}$ of RNase-free water. The running procedure was set to: $95^{\circ} \mathrm{C}$ for $3 \mathrm{~min}$, followed by 40 cycles of $95^{\circ} \mathrm{C}$ for $30 \mathrm{~s}$ and $58^{\circ} \mathrm{C}$ for $30 \mathrm{~s}$. All qPCR reactions were carried out in triplicate with at least three biological replicates. The relative expression levels were calculated using the $2^{-\Delta \Delta \mathrm{Ct}}$ method.

\subsection{Statistical Analysis}

The data of growth parameters as well as contents of chlorophyll, sugar, and starch were subjected to an analysis of variance (ANOVA) followed by Duncan's multiple range test at $p \leq 0.05$ using SAS (Statistical Analysis System, version 9.2, Cary, NC, USA) program. The interactions of the cytokinin and auxin in Table 2 were checked using the 2-way ANOVA F-test. The difference in gene expression levels between the control and plants treated with TDZ was checked by subjecting to the Student's $t$-test $(p \leq 0.05)$. 
Table 1. Primers used for the quantitative RT-PCR.

\begin{tabular}{|c|c|c|}
\hline Gene Name & Forward Primers $\left(5^{\prime}\right.$ to $\left.3^{\prime}\right)$ & Reverse Primers ( $5^{\prime}$ to $\left.3^{\prime}\right)$ \\
\hline $\mathrm{FaCKX7}$ & ATTATGGGAAGACGTGCTGAAA & TAACGACTTCAAGCTCCGTTAC \\
\hline FaIPT3 & GTGAAAGACAATACGTGCAAGT & ACTTCGGCCTTGTTATTGTAGA \\
\hline FaRR16 & GCAAGAGCATTGGAGTTTCTAG & TATCCTGTCATTCCTGGCATAC \\
\hline FaHP6 & GGGGATCCATTTGAATCAGTTG & GATCTGCTGTATTGGGTATCGA \\
\hline FaARF5 & TGGTTGGCATAAGGAGAGCA & GGCATGCCCTTGGATTGTAG \\
\hline FaSAUR & CTTTCAGCCAGATTAGGAGCTA & САААССТСТТСТТСТTGССТТС \\
\hline FaIAA4 & CCAAGCСТCСТССТTCСAAA & GAACATCCCACCGCTTTCTC \\
\hline FaWOX1 & GATGAAGATCAGACTCAAACGC & GATTCAGTGACGATTTCTCAGC \\
\hline FaSTM & TGGCTAGGTTAGAGGATGCG & GCTCTGGGTCTGGTTCTGAT \\
\hline FaLFY3 & CCACCAAGGTCACAAACCAG & GCGTAGCAGTGAACGTAGTG \\
\hline FaCUC2 & CCCAGGAAGAGTGGGTCATT & GAGACCGAGGAGGAAGAAGG \\
\hline FaCUC3 & TCTGCTGCTACTGCTTCTGT & GCAGCTGGGAGTTTGATGAG \\
\hline FaRGA1 & AAGCCGTCCAGCAGAACAA & GGTAAGGGCAGGTCTCGTAG \\
\hline FaSOC1 & GCAACTAGCATGATGAAGCAGATA & TGTTCACACTCСТСТССАACTG \\
\hline FaWUS & CACCAATGGAGCCACAAC & TCCCTCGATCTTCCCGTA \\
\hline
\end{tabular}

Table 2. The effect of cytokinin and auxin on the growth of strawberry plants.

\begin{tabular}{|c|c|c|c|c|c|}
\hline Cytokinin & Auxin & Number of Flowers & Plant Height (cm) & Leaf Length $(\mathrm{cm})$ & Leaf Width (cm) \\
\hline \multirow{4}{*}{ Control } & Water & $3.4^{\mathrm{c}-\mathrm{e}}$ & $15.6^{\mathrm{f}-\mathrm{h}}$ & $6.30^{c, d}$ & $5.18^{\mathrm{a}-\mathrm{e}}$ \\
\hline & IAA & $3.7^{c-e}$ & $14.1^{\mathrm{h}, \mathrm{i}}$ & $5.71^{\mathrm{d}-\mathrm{g}}$ & $4.68^{c-g}$ \\
\hline & IBA & $1.8^{\mathrm{e}}$ & $13.7^{\mathrm{h}, \mathrm{i}}$ & $5.43^{\mathrm{e}-\mathrm{h}}$ & $4.34^{\mathrm{f}-\mathrm{h}}$ \\
\hline & NAA & $4.3^{\mathrm{c}-\mathrm{e}}$ & $12.8^{i, j}$ & $3.89^{\mathrm{i}}$ & $3.12^{\mathrm{i}}$ \\
\hline \multirow{4}{*}{ BA } & Water & $4.0^{\mathrm{c}-\mathrm{e}}$ & $12.9^{\mathrm{i}, \mathrm{j}}$ & $5.37^{\mathrm{f}-\mathrm{h}}$ & $4.36^{\mathrm{f}-\mathrm{h}}$ \\
\hline & IAA & $3.9^{\mathrm{c}-\mathrm{e}}$ & $11.6^{j}$ & $4.81^{\mathrm{h}}$ & $4.30^{\mathrm{f}-\mathrm{h}}$ \\
\hline & IBA & $3.0^{\mathrm{d}, \mathrm{e}}$ & $19.2^{\mathrm{c}, \mathrm{d}}$ & $6.49^{b, c}$ & $4.66^{\mathrm{c}-\mathrm{h}}$ \\
\hline & NAA & $3.4^{\mathrm{c}-\mathrm{e}}$ & $17.9^{\mathrm{d}, \mathrm{e}}$ & $5.10^{\mathrm{g}, \mathrm{h}}$ & $4.73^{b-f}$ \\
\hline \multirow{4}{*}{ TDZ } & Water & $5.0^{b-d}$ & $24.0^{\mathrm{a}}$ & $8.03^{\mathrm{a}}$ & $5.74^{\mathrm{a}}$ \\
\hline & IAA & $5.0^{b-d}$ & $23.7^{\mathrm{a}}$ & $7.79^{a}$ & $5.38^{a, b}$ \\
\hline & IBA & $4.8^{b-d}$ & $22.2^{a, b}$ & $8.20^{a}$ & $5.83^{a}$ \\
\hline & NAA & $5.4^{\mathrm{a}-\mathrm{d}}$ & $20.7^{b, c}$ & $7.08^{b}$ & $5.33^{a-c}$ \\
\hline \multirow{4}{*}{ KT } & Water & $5.9^{a-d}$ & $14.9^{g, h}$ & $5.73^{\mathrm{d}-\mathrm{g}}$ & $4.61^{\mathrm{d}-\mathrm{h}}$ \\
\hline & IAA & $5.1^{\mathrm{a}-\mathrm{d}}$ & $16.7^{\mathrm{e}-\mathrm{g}}$ & $6.18^{\mathrm{c}, \mathrm{d}}$ & $4.78^{\mathrm{b}-\mathrm{f}}$ \\
\hline & IBA & $6.2^{\mathrm{a}-\mathrm{c}}$ & $18.4^{\mathrm{d}, \mathrm{e}}$ & $6.47^{b, c}$ & $4.98^{\mathrm{b}-\mathrm{f}}$ \\
\hline & NAA & $8.0^{\mathrm{a}}$ & $18.3^{\mathrm{d}, \mathrm{e}}$ & $5.34^{\mathrm{f}-\mathrm{h}}$ & $4.04^{\mathrm{g}, \mathrm{h}}$ \\
\hline \multirow{4}{*}{$\mathrm{ZT}$} & Water & $7.3^{\mathrm{a}, \mathrm{b}}$ & $17.4^{\mathrm{d}-\mathrm{f}}$ & $6.04^{c-f}$ & $4.88^{\mathrm{b}-\mathrm{f}}$ \\
\hline & IAA & $7.6^{\mathrm{a}, \mathrm{b}}$ & $17.8^{\mathrm{d}, \mathrm{e}}$ & $6.10^{c-e}$ & $5.23^{a-d}$ \\
\hline & IBA & $6.2^{\mathrm{a}-\mathrm{c}}$ & $15.2 \mathrm{~g}, \mathrm{~h}$ & $5.62^{\mathrm{d}-\mathrm{g}}$ & $4.52^{\mathrm{e}-\mathrm{h}}$ \\
\hline & NAA & $4.9^{\mathrm{b}-\mathrm{d}}$ & $15.2^{\mathrm{g}, \mathrm{h}}$ & $4.84^{\mathrm{h}}$ & $3.98^{\mathrm{h}}$ \\
\hline \multirow{3}{*}{$F$-test } & Cytokinin & $* * *$ & $* * *$ & $* * *$ & $* * *$ \\
\hline & Auxin & NS & $*$ & $* * *$ & $* * *$ \\
\hline & Cytokinin $\mathrm{x}$ Auxin & NS & $* * *$ & $*$ & $* *$ \\
\hline
\end{tabular}

Note: Lowercase letters indicate significant differences calculated by Duncan's multiple range test at $p \leq 0.05 ; \mathrm{NS},{ }^{*},{ }^{* *}$, and ${ }^{* * *}$ represent non-significant or significant by the 2-way ANOVA F-test at $p \leq 0.05,0.01$, and 0.001 , respectively.

\section{Results}

\subsection{Growth}

The crowns treated with TDZ and TDZ combined with IAA or IBA were larger than those of the other treatments (Figure 1a). There were also several branch crowns on every crown. Runners were only formed when BA was combined with IBA, TDZ alone, and when TDZ was combined with IAA or IBA (Figure 1b). The number of branch crowns was higher with TDZ or TDZ auxin (Figure 1c). Cytokinin increased the number of flowers 
per plant, while auxin had no effect (Table 2). KT combined with NAA, ZT alone, and ZT combined with IAA promoted flowering compared with the control. Furthermore, plant height, leaf length, and leaf width were greater with TDZ.

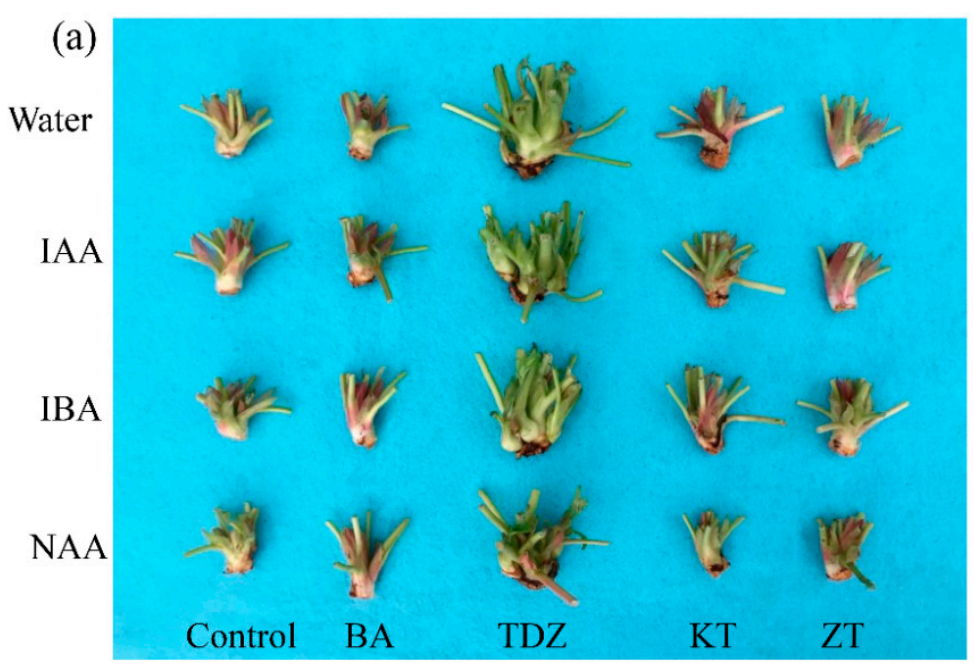

(b)

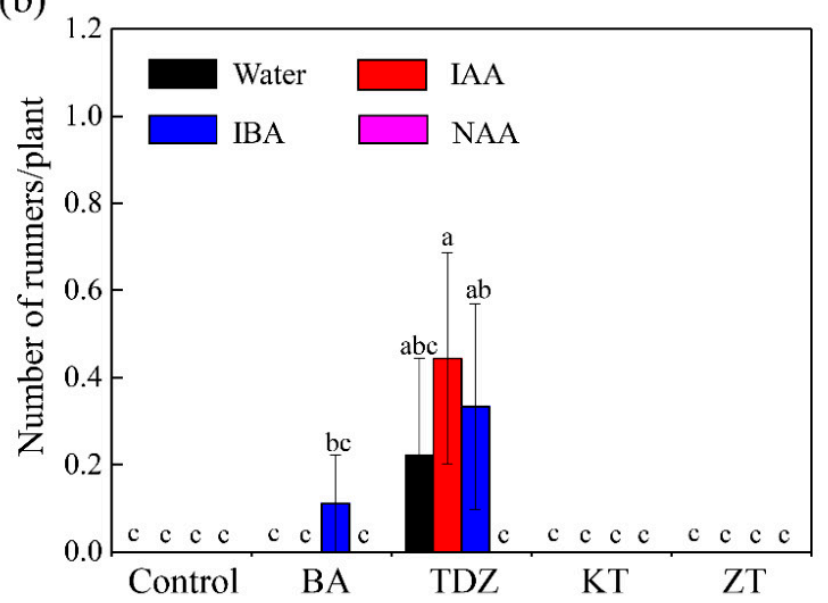

(c)

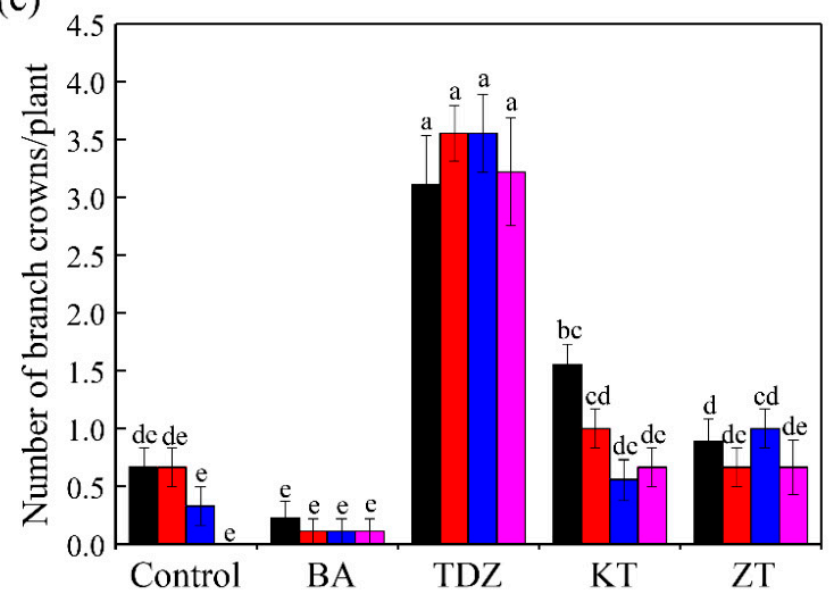

Figure 1. The effect of cytokinin and auxin on the morphology of the crown (a), and on the number of runners (b) and branch crowns (c) per plant in strawberry. Lowercase letters indicate significant differences calculated by Duncan's multiple range test at $p \leq 0.05$. Vertical bars indicate the standard error $(n=3)$.

\subsection{Chlorophyll}

The total chlorophyll contents were lower with TDZ and when TDZ was combined with auxins (Figure 2). BA and ZT combined with NAA promoted the chlorophyll contents compared with BA and ZT alone.

\subsection{Soluble Sugar and Starch}

The soluble sugar contents were lower with TDZ and TDZ combined with auxins (Figure 3a). Other cytokinins also reduced the soluble sugar contents. The starch contents were also lower with TDZ and ZT. (Figure 3b). However, the decrease in those treatments was less severe when combined with auxins. 


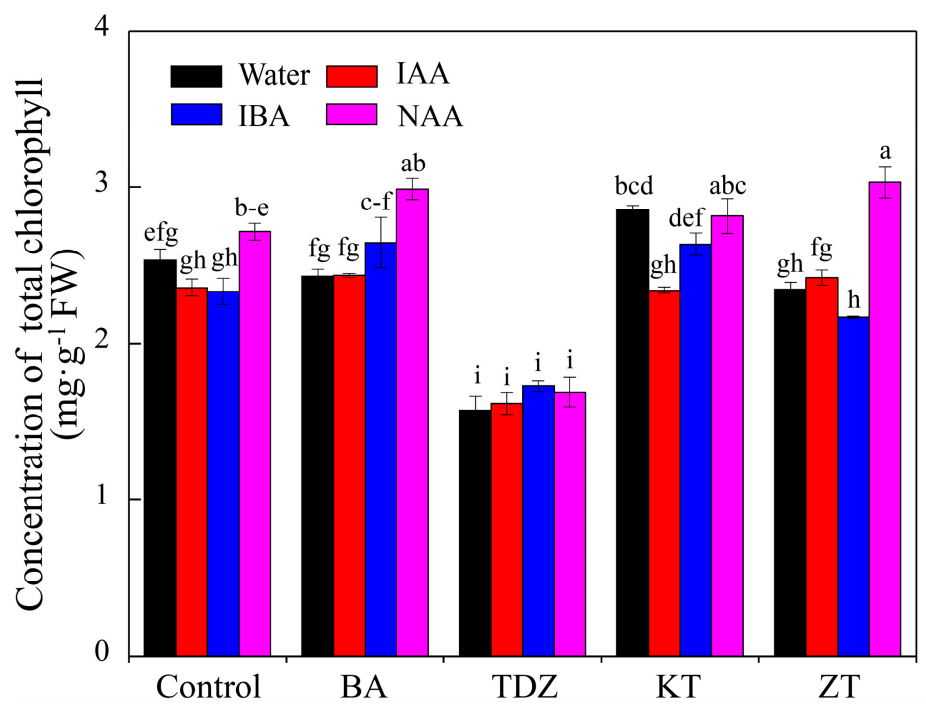

Figure 2. The effect of cytokinin and auxin on chlorophyll contents in strawberry leaves. FW: Fresh weight. Lowercase letters indicate significant differences calculated by Duncan's multiple range test at $p \leq 0.05$. Vertical bars indicate the standard error $(n=3)$.

(a)

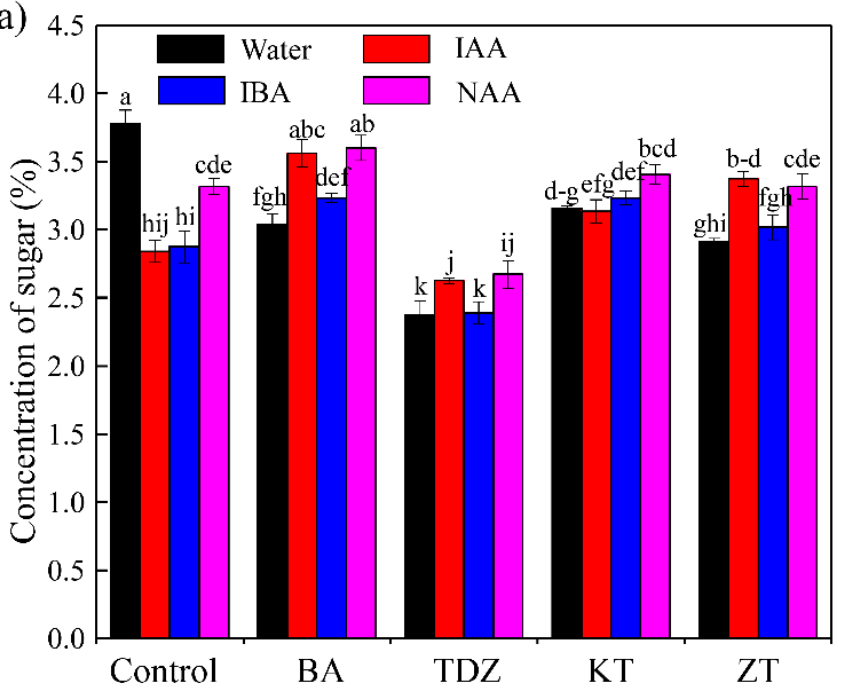

(b)

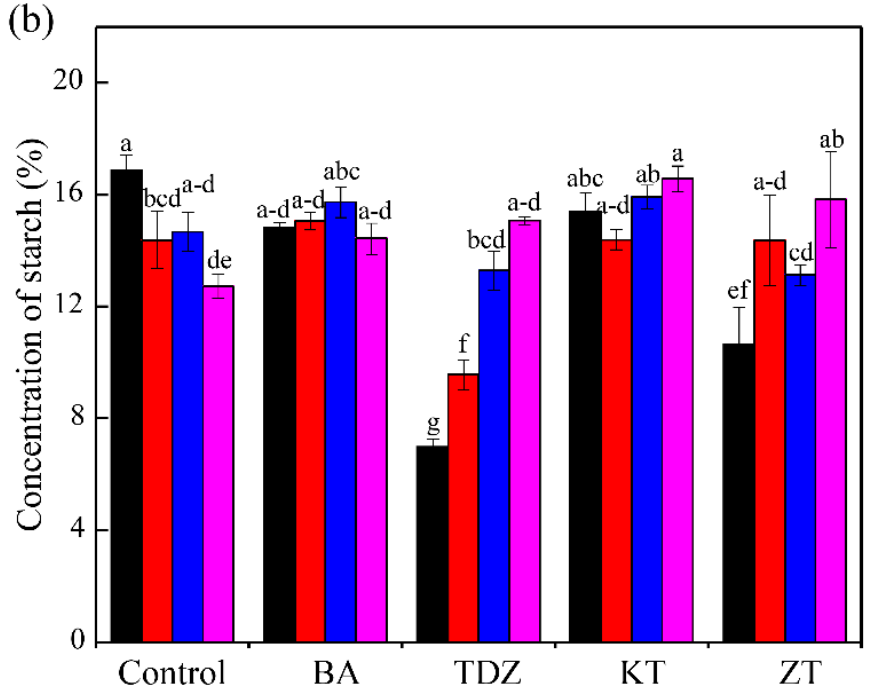

Figure 3. The effect of cytokinin and auxin on soluble sugar (a) and starch (b) contents in strawberry. Lowercase letters indicate significant differences calculated by Duncan's multiple range test at $p \leq 0.05$. Vertical bars indicate the standard error $(n=3)$.

\subsection{The Expression Level of Genes in the Crown}

The expression of two cytokinin-related genes, FaRR16 and FaHP6 were higher, while FaIPT3 lower with TDZ (Figure 4a). The auxin synthesis gene FaIAA4 was lower while FaSAUR was higher with TDZ (Figure $4 \mathrm{~b}$ ). The expression of meristem-related transcriptional factors including FaWOX1, FaLFY3, FaCUC3, FaRGA1, and FaWUS were higher with TDZ (Figure 4c). The transcriptional factors FaSTM and FaSOC1 were lower with TDZ. The expression level of cytokinin synthesis related gene $F a C K X 7$, auxin-related gene FaARF5, and transcriptional factor $\mathrm{FaCUC2}$ were similar in the control and plants treated with TDZ. 
(a)

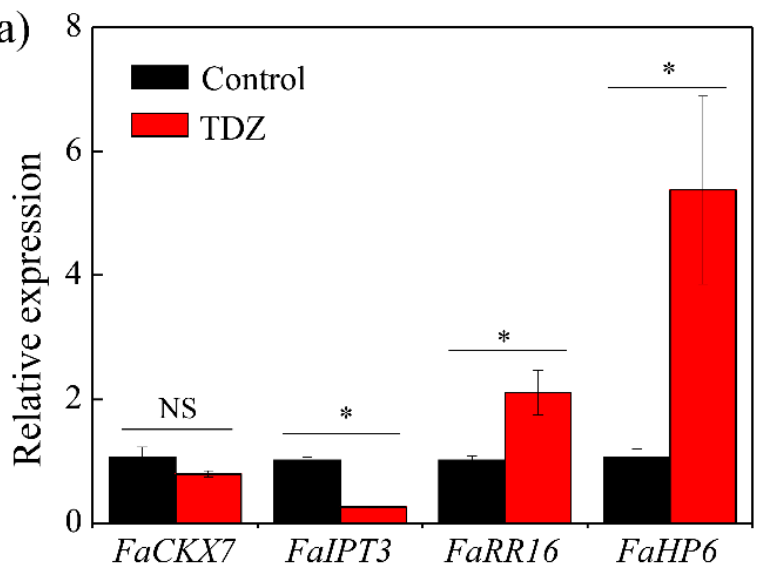

(b)

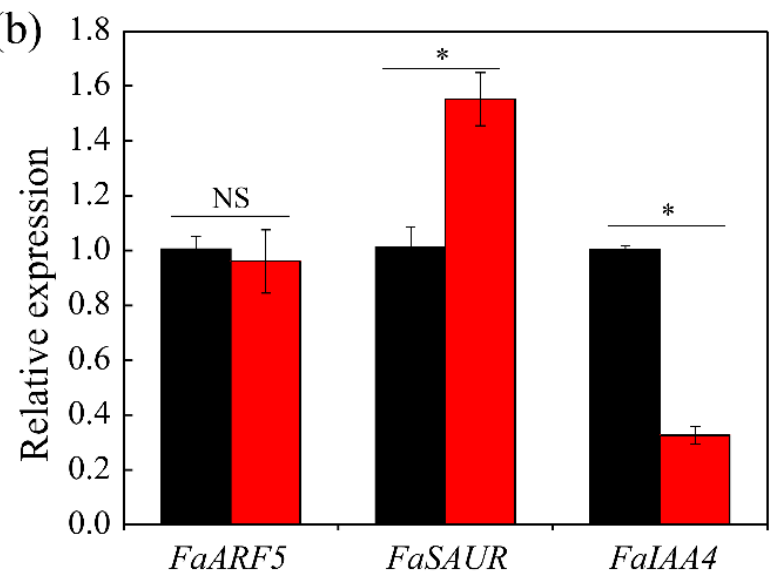

(c)

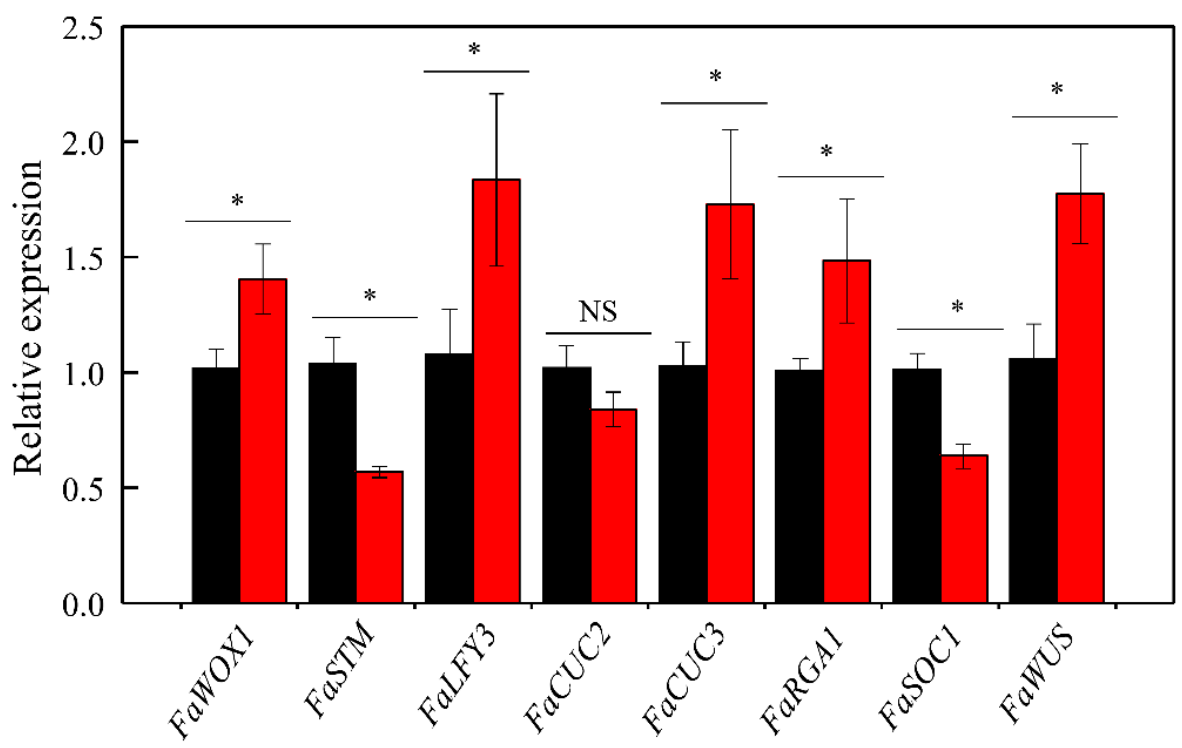

Figure 4. The effect of TDZ on the cytokinin (a) and auxin (b) metabolism-related genes and meristem-related transcriptional factors (c) in strawberry. The significant differences were calculated by Student's $t$-test. NS, and * represent non-significant or significant at $p \leq 0.05$, respectively.

\section{Discussion}

Both runners and branch crowns are essential for strawberry propagation. The number of runners and branch crowns were higher with TDZ in this study. The TDZ has gained a considerable attention due to its efficient role in stimulating the plant cell division [18]. It exhibits stronger and longer-lasting effects than natural cytokinins do. Besides, it was found that TDZ has shown both cytokinin- and auxin-like effects $[19,20]$. These particular characteristics of TDZ significantly promoted the proliferation of axillary shoots and released the lateral bud dormancy in plants [21-23], which could be the reason that strawberry plants treated with TDZ produced more runners and branch crowns in this study. Furthermore, the number of branch crowns per plant was greater than the number of runners with TDZ. This means that the axillary buds preferentially tended to differentiate into branch crowns in this study. Researchers found that the fate of the axillary buds of strawberry whether develop into runners or branch crowns is regulated by environmental conditions [3]. Since this experiment was conducted in a glasshouse in the winter, the low temperature and short photoperiod were more conducive for formation of branch crowns than runners. Thus, the fate of the axillary buds may also be controlled by the environmental conditions indirectly in addition to direct influence of TDZ. 
The growth of the strawberry plants was enhanced, while chlorophyll, sugar, and starch contents were lower with TDZ in this study. On the one hand, it was reported that TDZ can enhance the plant response to cytokinin signals [18]. On the other hand, researchers found that cytokinins are crucial for photosynthesis [24]. Thus, we speculated that the photosynthesis may be promoted to some extent at the beginning, and more carbohydrates were produced for growth of axillary bud and plant. Nevertheless, another work showed that TDZ uncouples ATP formation in isolated chloroplasts or mitochondria of spinach (Spinacia oleracea), and therefore, inhibits energy conservation in respiration and photosynthesis [25], thereby the energy was not sufficient for continued plant growth, and chlorophyll, sugar, and starch contents decreased later. Furthermore, TDZ is famous for its use for the defoliation in cotton (Gossypium hirsutum). Suttle [26] demonstrated that TDZ induced endogenous ethylene in leaf blades and abscission zone explants, and the ethylene then activated the abscission zone tissue, which caused the leaves to drop. This might be another reason for the decrease of chlorophyll contents in this experiment.

The cytokinin, auxin, and transcription factor-related genes are closely related to axillary bud growth. Since FaIPT3 and FaCKX7 are involved in cytokinin biosynthesis and degradation, respectively, while FaRR16 and FaHP6 are related to cytokinin signal transduction pathway [27-29]. The lower expression levels of FaIPT3 and higher expression levels of FaRR16 and FaHP6 in crowns with TDZ indicated that TDZ promotes the growth of axillary bud through activation of cytokinin signal transduction rather than synthesis of more cytokinin. This might be the reason why the expression level of cytokinin degradation gene FaCKX7 remains unchanged. As for auxin-related genes, the SAUR family negatively regulates the synthesis and transport of auxin, while $I A A 4$ is positively correlated with auxin synthesis [30-32]. In this study, the higher expression level of FaSAUR and the lower expression level of FaIAA4 indicated that the auxin synthesis was inhibited by TDZ, which is beneficial to axillary bud growth. The gene $A R F$ plays a key role in regulating the expression of auxin response genes [33]. As the expression level of FaARF5 between the control and TDZ treated plants did not show any differences, we speculate that TDZ did not affect the signal transduction of auxins. The transcription factor $L F Y$ could regulate the expression of CUC indirectly [34,35], and CUC2 and CUC3 interact with STM to activate the initiation of AXM [36]. The higher expression level of FaLFY3 and FaCUC3 with TDZ indicated that TDZ regulated these two genes to activate the initiation of AXM. However, the STM-expressing cells 'move' upward toward the leaf, their neighboring cells re-differentiate to AXM progenitor cells [37]. This might be the reason why the lower expression level of FaSTM in strawberry with TDZ, because the new branch crowns already formed at the time of sampling. The WUS is crucial for determination of stem cell fate in the shoot apex meristem [38], and WOX genes are originated from WUS [39]. Higher expression levels of FaWUS and FaWOX1 were detected in the plant supplied with TDZ, indicating that TDZ induced these genes to promote the differentiation of the axillary buds in this experiment. In addition, gibberellin (GA) is essential for runner induction. The gene FveRGA1 is a negative regulator of GA signaling [40], and therefore, negatively regulates the runner formation [41]. The transcription factor FvSOC1, which could activate the expression of GA biosynthetic genes, positively regulates the runner formation [42]. The expression level of FaRGA1 increased, while the expression level of FaSOC1 decreased in this study, indicating suppressed development of axillary buds into runners, and thus, more branch crowns formed. However, whether the regulation of these two genes was controlled by the TDZ directly or by the environment indirectly needs to be studied further.

Cultivated strawberries are usually propagated in spring and summer [43]. The strawberry plants tend to produce flowers and fruits during winter, and the propagation in winter is more difficult than in other seasons because of the short day and low temperature [44]. Our results suggested that TDZ could be an effective chemical to break the dormancy of the axillary buds of strawberry plants, and the induction of both runners and branch crowns may be possible in winter seasons. Thus, TDZ can be used as an auxiliary tool for strawberry propagation in the future. Moreover, as the growth of the 
plants was also promoted by TDZ, and this may also benefit the fruit productivity of the strawberry crops.

\section{Conclusions}

The cytokinin TDZ was the most effective for promoting axillary bud growth in strawberry among cytokinins, auxins, and combinations of cytokinins and auxins used in this research. Although both runners and branch crowns were increased, preferentially more branch crowns than runners were formed with the foliar application of TDZ. The growth of the strawberry plants increased with TDZ, whereas contents of chlorophyll, soluble sugar, and starch decreased. Moreover, TDZ activated the cytokinin-signal-transduction pathway and upregulated some transcriptional factors including FaLFY3, FaCUC3, FaWUS, and FaWOX1.

Author Contributions: Conceptualization, B.R.J. and Y.L.; methodology, B.R.J. and Y.L.; software, Y.L. and J.H.; validation, B.R.J.; formal analysis, B.R.J., Y.L., and J.H.; investigation, Y.L., J.H., J.X., and G.G.; resources, B.R.J.; data curation, B.R.J., Y.L., and J.H.; writing-original draft preparation, Y.L.; writing-review and editing, B.R.J., Y.L., and J.H.; supervision, B.R.J.; project administration, B.R.J. and Y.L. All authors have read and agreed to the published version of the manuscript.

Funding: This research was funded by the Korea Institute of Planning and Evaluation for Technology in Food, Agriculture, Forestry and Fisheries (Project No. 118078-2). Y.L. was supported by a scholarship from China Scholarship Council, J.X. and J.H. were supported by a scholarship from the BK21 Program, the Ministry of Education, Republic of Korea.

Institutional Review Board Statement: This study did not involve humans or animals.

Informed Consent Statement: This study did not involve humans.

Data Availability Statement: The data presented in this study are available on request from the corresponding author.

Conflicts of Interest: The authors declare no conflict of interest.

\section{References}

1. Savini, G.; Neri, D.; Zucconi, F.; Sugiyama, N. Strawberry growth and flowering: An architectural model. Int. J. Fruit Sci. 2005, 5, 29-50. [CrossRef]

2. Tenreira, T.; Lange, M.J.P.; Lange, T.; Bres, C.; Labadie, M.; Monfort, A.; Hernould, M.; Rothan, C.; Denoyes, B. A specific gibberellin 20-oxidase dictates the flowering-runnering decision in diploid strawberry. Plant Cell 2017, 29, 2168-2182. [CrossRef]

3. Caruana, J.C.; Sittmann, J.W.; Wang, W.; Liu, Z. Suppressor of runnerless encodes a della protein that controls runner formation for asexual reproduction in strawberry. Mol. Plant 2018, 11, 230-233. [CrossRef]

4. Hytönen, T.; Palonen, P.; Mouhu, K.; Junttila, O. Crown branching and cropping potential in strawberry (fragaria ananassa duch.) can be enhanced by daylength treatments. J. Hortic. Sci. Biotechnol. 2004, 79, 466-471. [CrossRef]

5. Booker, J.; Chatfield, S.; Leyser, O. Auxin acts in xylem-associated or medullary cells to mediate apical dominance. Plant Cell 2003, 15, 495-507. [CrossRef] [PubMed]

6. Shimizu-Sato, S.; Mori, H. Control of outgrowth and dormancy in axillary buds. Plant Physiol. 2001, 127, 1405-1413. [CrossRef] [PubMed]

7. Qiu, Y.; Guan, S.C.; Wen, C.; Li, P.; Gao, Z.; Chen, X. Auxin and cytokinin coordinate the dormancy and outgrowth of axillary bud in strawberry runner. BMC Plant Biol. 2019, 19, 528. [CrossRef] [PubMed]

8. Kang, C.; Li, Y.; Feng, J.; Cheng, L.; Dai, C.; Liu, Z. Gene expression profiling of the shoot meristematic tissues in woodland strawberry fragaria vesca. Front. Plant Sci. 2019, 10, 1624.

9. Mason, M.G.; Ross, J.J.; Babst, B.A.; Wienclaw, B.N.; Beveridge, C.A. Sugar demand, not auxin, is the initial regulator of apical dominance. Proc. Natl. Acad. Sci. USA 2014, 111, 6092-6097. [CrossRef]

10. Bertheloot, J.; Barbier, F.; Boudon, F.; Perez-Garcia, M.D.; Péron, T.; Citerne, S.; Dun, E.; Beveridge, C.; Godin, C.; Sakr, S. Sugar availability suppresses the auxin-induced strigolactone pathway to promote bud outgrowth. New Phytol. 2020, 225, 866-879. [CrossRef]

11. Li, Y.; Hu, J.; Wei, H.; Jeong, B.R. A long-day photoperiod and 6-benzyladenine promote runner formation through upregulation of soluble sugar content in strawberry. Int. J. Mol. Sci. 2020, 21, 4917. [CrossRef]

12. Werner, T.; Motyka, V.; Strnad, M.; Schmülling, T. Regulation of plant growth by cytokinin. Proc. Natl. Acad. Sci. USA 2001, 98, 10487-10492. [CrossRef]

13. Barciszewski, J.; Massino, F.; Clark, B.F. Kinetin-A multiactive molecule. Int. J. Biol. Macromol. 2007, 40, 182-192. [CrossRef] 
14. Ren, B.; Hu, J.; Zhang, J.; Dong, S.; Liu, P.; Zhao, B. Spraying exogenous synthetic cytokinin 6-benzyladenine following the waterlogging improves grain growth of waterlogged maize in the field. J. Agron. Crop Sci. 2019, 205, 616-624. [CrossRef]

15. Nisler, J.; Kopečný, D.; Končitíková, R.; Zatloukal, M.; Bazgier, V.; Berka, K.; Zalabák, D.; Briozzo, P.; Strnad, M.; Spíchal, L. Novel thidiazuron-derived inhibitors of cytokinin oxidase/dehydrogenase. Plant Mol. Biol. 2016, 92, 235-248. [CrossRef] [PubMed]

16. Piotrowska-Niczyporuk, A.; Bajguz, A. The effect of natural and synthetic auxins on the growth, metabolite content and antioxidant response of green alga chlorella vulgaris (trebouxiophyceae). Plant Growth Regul. 2014, 73, 57-66. [CrossRef]

17. Wang, M.; Xiao, J.; Wei, H.; Jeong, B.R. Supplementary light source affects growth and development of carnation 'dreambyul'cuttings. Agronomy 2020, 10, 1217. [CrossRef]

18. Nisler, J. TDZ: Mode of action, use and potential in agriculture. In Thidiazuron: From Urea Derivative to Plant Growth Regulator; Springer: Berlin/Heidelberg, Germany, 2018; pp. 37-59.

19. Murthy, B.; Murch, S.; Saxena, P.K. Thidiazuron: A potent regulator of in vitro plant morphogenesis. Vitr. Cell. Dev. Biol. Plant 1998, 34, 267. [CrossRef]

20. Sankhla, N.; Mackay, W.; Davis, T. Reduction of flower abscission and leaf senescence in cut phlox inflorescences by thidiazuron. In Proceedings of the XXVI International Horticultural Congress: Issues and Advances in Postharvest Horticulture, Toronto, ON, Canada, 11-17 August 2002; Volume 628, pp. 837-841.

21. Faisal, M.; Ahmad, N.; Anis, M. Shoot multiplication in rauvolfia tetraphylla 1. Using thidiazuron. Plant Cell Tissue Organ Cult. 2005, 80, 187-190. [CrossRef]

22. Mroginski, E.; Rey, H.Y.; Gonzalez, A.M.; Mroginski, L.A. Thidiazuron promotes in vitro plant regeneration of arachis correntina (leguminosae) via organogenesis. J. Plant Growth Regul. 2004, 23, 129-134. [CrossRef]

23. Verma, M.; Bansal, Y.K. Effect of a potent cytokinin thidiazuron (tdz) on in vitro regeneration of hedychium coronarium $\mathrm{j}$. Koenig-A valuable medicinal plant. Int. J. Rec. Biotech. 2014, 2, 38-44.

24. Chernyad'ev, I. The protective action of cytokinins on the photosynthetic machinery and productivity of plants under stress. Appl. Bioch. Microbiol. 2009, 45, 351-362. [CrossRef]

25. Hauska, G.; Trebst, A.; Kötter, C.; Schulz, H. 1, 2, 3-thiadiazolyl-pheny 1-ureas, new inhibitors of photosynthetic and respiratory energy conservation. Z. Für Nat. C 1975, 30, 505-510. [CrossRef]

26. Suttle, J.C. Involvement of ethylene in the action of the cotton defoliant thidiazuron. Plant Physiol. 1985, 78, 272-276. [CrossRef] [PubMed]

27. Kudo, T.; Kiba, T.; Sakakibara, H. Metabolism and long-distance translocation of cytokinins. J. Integr. Plant Biol. 2010, 52, 53-60. [CrossRef] [PubMed]

28. Tao, J.; Sun, H.; Gu, P.; Liang, Z.; Chen, X.; Lou, J.; Xu, G.; Zhang, Y. A sensitive synthetic reporter for visualizing cytokinin signaling output in rice. Plant Methods 2017, 13, 1-9. [CrossRef]

29. Suzaki, T.; Ito, M.; Kawaguchi, M. Genetic basis of cytokinin and auxin functions during root nodule development. Front. Plant. Sci. 2013, 4, 42. [CrossRef] [PubMed]

30. Markakis, M.N.; Boron, A.K.; Van Loock, B.; Saini, K.; Cirera, S.; Verbelen, J.-P.; Vissenberg, K. Characterization of a small auxin-up rna (saur)-like gene involved in arabidopsis thaliana development. PLoS ONE 2013, 8, e82596. [CrossRef]

31. Bai, Q.; Hou, D.; Li, L.; Cheng, Z.; Ge, W.; Liu, J.; Li, X.; Mu, S.; Gao, J. Genome-wide analysis and expression characteristics of small auxin-up rna (saur) genes in moso bamboo (phyllostachys edulis). Genome 2017, 60, 325-336. [CrossRef]

32. Ziliotto, F.; Corso, M.; Rizzini, F.M.; Rasori, A.; Botton, A.; Bonghi, C. Grape berry ripening delay induced by a pre-véraison naa treatment is paralleled by a shift in the expression pattern of auxin-and ethylene-related genes. BMC Plant. Biol. 2012, 12, 1-15. [CrossRef]

33. Li, S.-B.; Xie, Z.-Z.; Hu, C.-G.; Zhang, J.-Z. A review of auxin response factors (arfs) in plants. Front. Plant Sci. 2016, 7, 47. [CrossRef]

34. Raman, S.; Greb, T.; Peaucelle, A.; Blein, T.; Theres, K. Interplay of mir164, cup-shaped cotyledon genes and lateral suppressor controls axillary meristem formation in Arabidopsis thaliana. Plant. J. 2008, 55, 65-76. [CrossRef]

35. Chahtane, H.; Vachon, G.; Le Masson, M.; Thévenon, E.; Périgon, S.; Mihajlovic, N.; Kalinina, A.; Michard, R.; Moyroud, E.; Monniaux, M. A variant of leafy reveals its capacity to stimulate meristem development by inducing rax1. Plant. J. 2013, 74, 678-689. [CrossRef]

36. Cao, X.; Jiao, Y. Control of cell fate during axillary meristem initiation. Cell. Mol. Life Sci. 2020, 77, 2343-2354. [CrossRef]

37. Yang, M.; Jiao, Y. Regulation of axillary meristem initiation by transcription factors and plant hormones. Front. Plant. Sci. 2016, 7, 183. [CrossRef] [PubMed]

38. Su, Y.H.; Zhao, X.Y.; Liu, Y.B.; Zhang, C.L.; O’Neill, S.D.; Zhang, X.S. Auxin-induced wus expression is essential for embryonic stem cell renewal during somatic embryogenesis in Arabidopsis. Plant. J. 2009, 59, 448-460. [CrossRef] [PubMed]

39. van der Graaff, E.; Laux, T.; Rensing, S.A. The wus homeobox-containing (wox) protein family. Genome Biol. 2009, 10, 248. [CrossRef]

40. Alyssa, D.; Jung, H.S.; Sun, T.P. The DELLA motif is essential for gibberellin-induced degradation of RGA. Proc. Natl. Acad. Sci. USA 2001, 98, 14162-14167.

41. Li, W.; Zhang, J.; Sun, H.; Wang, S.; Chen, K.; Liu, Y.; Li, H.; Ma, Y.; Zhang, Z. Fverga1, encoding a della protein, negatively regulates runner production in fragaria vesca. Planta 2018, 247, 941-951. [CrossRef] [PubMed] 
42. Mouhu, K.; Kurokura, T.; Koskela, E.A.; Albert, V.A.; Elomaa, P.; Hytönen, T. The fragaria vesca homolog of suppressor of overexpression of constans1 represses flowering and promotes vegetative growth. Plant. Cell 2013, 25, 3296-3310. [CrossRef]

43. Li, Y.; Xiao, J.; Hu, J.; Jeong, B.R. Method of silicon application affects quality of strawberry daughter plants during cutting propagation in hydroponic substrate system. Agronomy 2020, 10, 1753. [CrossRef]

44. Gaston, A.; Perrotte, J.; Lerceteau-Köhler, E.; Rousseau-Gueutin, M.; Petit, A.; Hernould, M.; Rothan, C.; Denoyes, B. PFRU, a single dominant locus regulates the balance between sexual and asexual plant reproduction in cultivated strawberry. J. Exp. Bot. 2013, 64, 1837-1848. [CrossRef] [PubMed] 